BÁLINT CSENDES, Ph.D. ${ }^{1}$

(Corresponding author)

E-mail: csendes.balint@kti.hu

GÁBOR ALBERT ${ }^{1}$

E-mail: albert.gabor@kti.hu

NORINA SZANDER, Ph.D. ${ }^{1}$

E-mail: szander.norina@kti.hu

ANDRÁS MUNKÁCSY, Ph.D. ${ }^{1}$

E-mail: munkacsy.andras@kti.hu

${ }^{1}$ KTI Institute for Transport Sciences Non Profit Ltd.

Than Károly u. 3-5. 1119 Budapest, Hungary
Science in Traffic and Transport Original Scientific Paper Submitted: 14 July 2021 Accepted: 22 Oct. 2021

\title{
WHERE TRUCK DRIVERS STOP - APPLICATION OF VEHICLE TRACKING DATA FOR THE IDENTIFICATION OF REST LOCATIONS AND DRIVING PATTERNS
}

\begin{abstract}
Road transport plays an essential role in freight transport throughout Europe, therefore, conditions that may hinder seamless operations in this sector require thorough consideration for evidence-based action. Critical amongst these key conditions is how, when, and where truck drivers stop, as a common set of rules strictly regulates their driving times and rest periods, which causes mandatory interruptions in the supply chains. However, approximating reliable estimations of freight traffic flows and road infrastructure usage constitutes a considerable challenge for researchers. This paper presents a robust data processing approach to designate rest area stops and to calculate the pertaining driving and rest times. Drawing on the abundance of navigation information provided by private fleet toll registration services, a comprehensive spatial-temporal truck stop database on all major rest areas along the toll road network in Hungary has been compiled. Based on the assessment and comparison of driving and rest times, driving and parking times have been analysed, including micro-scale analysis of particular rest areas. Both the methods applied and the results achieved can be of strategic interest to better understand truck driving patterns, as well as to develop targeted and cost-effective measures to streamline freight transport operations in other contexts.
\end{abstract}

\section{KEYWORDS}

GNSS tracking; truck rest areas; mandatory rest time; truck traffic regulations; truck driving patterns; road freight transport.

\section{INTRODUCTION}

In Hungary, an EU member state with a surface area of $93,030 \mathrm{~km}^{2}$ and 9.8 million inhabitants, road transport is the dominant mode in moving freight: 3.7 times more cargo was transported on road than by rail in 2020 [1]. A total of $1,738 \mathrm{~km}$ of highways (motorways and expressways) and 7,017 km of main roads serve road traffic as of 2020, and a distance-based electronic toll system of heavy vehicles is in place across approximately $6,500 \mathrm{~km}$ of this network.

The key roads belong to the Mediterranean, Orient/East-Med and Rhine-Danube corridors crossing Hungary, forming part of the TEN-T network at a length of $1,474 \mathrm{~km}$. They also function as the main arteries of national and international freight transport in the country. Along $1,319 \mathrm{~km}$ of this network, there are 184 rest stops with facilities for truck drivers. The Annual Average Daily Traffic Flow (AADT, 2019 ) is higher than 40,000 vehicles on $30 \%$ of the TEN-T network, and the proportion of total traffic comprising HGVs is more than $20 \%$ on $42 \%$ of the TEN-T network [2]. With regards to traffic composition, in the Hungarian sections of the Orient/EastMed route Vienna (AT)-Budapest (HU)-Belgrade (RS), the average ratio of trucks was $21 \%$ in number of vehicles and $39 \%$ in PCU (passenger car unit) in 2019, while the capacity utilisation on some sections - mainly close to the capital city of Budapest - exceeds $100 \%$ of the tolerable traffic volume [3]. 
The regulatory framework in the European Union, completely integrated into the Hungarian law, specifies the driving time, break, and rest period rules for drivers engaged in national and international road transport. These regulations have essential influence on the use of parking lots designated to heavy vehicles. The most relevant regulations in the European Union are about the harmonisation of certain pieces of social legislation relating to road transport [4] and about the maximum daily and weekly driving times, minimum breaks, and daily and weekly rest periods [5]. As a general rule, the critical driving time is 4.5 hours, i.e., drivers are required to take a break of at least 45 minutes before this time limit; however, this short break may be divided into two sections, one being at least 15 minutes and the other 30 minutes. The drivers must not drive more than 9 hours a day in total (still respecting the aforementioned 4.5 hours limit, which is a hard constraint), which may be extended under specific circumstances, to a maximum of 10 hours, not more than twice a week. Furthermore, as of 2021, Hungary is one of those 14 EU member states where traffic bans (truckstop) restrict the traffic of trucks on weekends and during national holidays. During traffic bans, drivers have to stop irrespective of their driving time (with some exceptions, e.g. the transport of live animals).

In light of the importance of the transport of goods for citizens, businesses, and manufacturing industries, current EU policies, particularly the recent Sustainable and Smart Mobility Strategy [6], aim to ensure uninterrupted freight transport operations. This may refer to a variety of aspects of how the EU's single market is expected to operate, including - among others - interoperability between modes, inter- and multimodality, integrated digital services, and paperless procedures. Road transport plays an essential role in freight transport throughout Europe [7]. Therefore, conditions that may hinder seamless operation in this sector require thorough consideration for evidence-based action. Critical amongst these key conditions is how, when, and where truck drivers rest, as a common set of EU rules (with some exceptions and national derogations) strictly regulate their driving times and rest periods, causing mandatory interruptions in the transport flow in the supply chains. Bearing in mind the rationale behind this measure (particularly health and safety of the personnel, road safety, as well as fair competition), one of the main challenges of this sector is to ensure efficient use of resources while adhering to applicable rules and regulations. In order to keep up with schedules, logistics service providers and truck drivers need to be sure that they will be able to stop and park the vehicle and cargo safely in a designated parking place or area. Overdriving (to find a rest location or any other reasons) is not only monitored and strictly sanctioned by the transport authorities but also imposes safety risks and health implications in relation to stress and fatigue. Stopping earlier in order to ensure timely access to an adequate rest location increases also the risk of transport delays and reduces competitiveness of service providers. For the above reasons, a well-managed, safe, and secure truck parking network along main (particularly TEN-T) road corridors is of strategic importance for the competitiveness of the EU road freight transport sector.

Identifying the characteristics of the rest areas within Central Europe for an infrastructure that supports hours-of-service compliance and seamless freight flow requires substantially more research. The present research aims to reveal driving and resting patterns of truck drivers, to map the use of rest areas along road networks, and analyse the use of the dedicated infrastructure on micro level, i.e., at specific rest areas. This is presented in the form of a case study in Hungary applying a GNSS-data-based approach to investigate the routing of heavy goods vehicles (HGVs) in the specific context of highways and main roads in Hungary. It is expected that the outcomes will contribute to the better understanding of spatial and temporal distribution of parking demand, characteristics of journeys of critical length, as well as the actual use of rest areas beyond the case of a particular country.

The above mentioned general research aims are translated into the following specific research questions to guide the analysis:

RQ1: How can fleet tracking data reflect the temporal driving patterns and rest area usage?

RQ2: What are the spatial characteristics of rest area utilisation?

RQ3: How can spatial temporal data support an infrastructural (qualitative) analysis of highway rest areas?

This paper is organised as follows: first, a brief review of truck parking related literature is presented. This is followed by an overview of the case study. In the methodology section, data as well as approaches and main challenges of data processing 
are introduced. Results and key findings of the spatio-temporal analyses are broken down into subchapters answering the research questions. Finally, findings are summarised and the potential fields of further application are presented in the Conclusion.

\section{LITERATURE REVIEW}

Truck parking studies in North America and Europe usually investigate the use and occupancy rates of rest areas; many of them indicate that the number of designated parking places are insufficient and that it is often difficult for drivers to find a place to rest in compliance with pertinent regulations [8-10]. In spite of the relevance of understanding patterns in driving and rest times, along with the use of rest areas, the topic has remained rather underresearched in Europe [11]. In terms of methodology, the earliest studies in the field are the so-called overnight studies, which are essentially field studies: researchers spent a day and a night in the rest areas (every year on specific days) registering the arrival of trucks and the time spent, while also interviewing the commercial vehicle drivers $[12,13]$. To eliminate the bias caused by depending on the memory of the respondents, a 14-day truck parking travel diary was created [14], and provided better insights into aspects that overnight studies could not explore, such as number of locations searched, frequency of resting at unauthorised spots, total non-productive time spent searching for parking and factors influencing stop location choice. From the drivers' perspective, finding a safe and adequate parking area was surveyed in the Pacific Northwest of the USA by Anderson et al. [15], indicating that more than half of the truck drivers occasionally decide to park at highway ramps and shoulders due to lack of available parking or infrastructural features that make it difficult to manoeuvre an HGV.

The scientific interest increased in light of the large amounts of digital traffic data generated on itineraries of heavy vehicles. With the spreading of GNSS (Global Navigation Satellite Systems) technology researchers started to incorporate navigation and fleet tracking data into their studies, in combination with the results of the overnight studies [8] and WIM (weight-in-motion) sensors [16]. These studies established an expansion factor to their respective study area, which estimates and attempts to mitigate the deviation coming from the different data collection methods. Another GPS-based approach applied econometric methods to link rest area occu- pancy rates with possible influencing factors, such as commercial vehicle flow, average speed, number of lanes, time of day, and usage of shoulders and ramps of rest areas in Tennessee, USA [17]. The authors demonstrated that studies performed on GPS data are significantly more cost-effective than field studies and are also more informative at the same time, as a continuous and large-scale data stream can be analysed. Moreover, with the truck IDs, movements and behavioural patterns can be traced accurately and, most of all, they can be processed with GIS applications.

Nevland et. al [18] created a classification scheme that highlights a set of HGV parking places that were virtually invisible to researchers as they did not fall in the categories of authorised parking places (such as public rest areas and fuel stations, weigh stations, open access HGV parking, limited access HGV parking, authorised roadside parking), rather being unauthorised spots (unauthorised roadside parking, unauthorised highway ramp parking, unauthorised parking on public property, unauthorised parking on private property). Analysing the GPS data of commercial vehicles in their study setting, the latter collection of parking places even surpassed the area of the authorised property parcels, proving that traditional data collection methods could not capture a massive portion of parking spots in use. As Karam et al. [19] stated, European studies are missing in the field, and they also acknowledge the difficulty of acquiring fleet tracking data. According to them, this is likely due to the reluctance of logistics companies to share sensitive data regarding their operations, as their performance metrics, the extent of their capabilities, or even location of their business partners could be assumed.

\section{METHODOLOGY}

In order to reveal driving and rest patterns, two databases have been created. Figure 1 illustrates the methodology, including the data analysis steps and the connection of the individual data sources.

\subsection{Processing of the GNSS tracking dataset}

Before 2016, traffic surveys in Hungary mainly operated with data sampling techniques and interviews. Since then, owing to the electronic fleet tracking and toll calculation methods, there is the possibility to draw on the potential of GNSS data. 


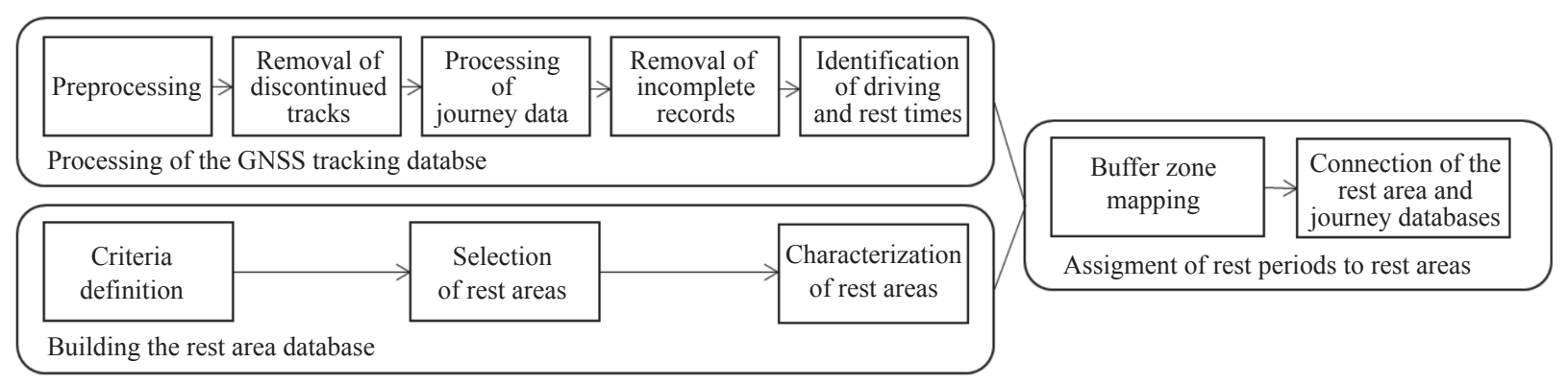

Figure 1 - Data processing steps of the analysis

The precision and representativeness of the tracking dataset renders it a powerful tool for the characterisation of the most popular destinations, routes, and other driving patterns. Most of the vehicles above 3.5 tonnes running on the toll roads in Hungary have been using OBUs (On-Board Units) since 2013.

The databases of three of the largest fleet tracking service providers, which cover about half of the entire Hungarian toll-paying HGV fleet, have been used for the first time in 2016 for the national truck origin/destination matrix analysis [20,21]. The acquired geopositioning data which covers October and November 2015 also contains timestamps and anonymised vehicle ID codes [22]. The extraction of spatial and temporal journey parameters required further data processing; however, the dataset can be regarded as representative information on vehicles weighing above 3.5 tonnes and suitable for the production of reliable and undistorted statistical estimations. For the present study, data of 100,000 randomly selected routes from the three service providers have been processed, as follows:

- In the first step, pre-processing of the GNSS tracks, interim stops - such as stop-and-go situations and manoeuvres at traffic obstacles (e.g. traffic light locations) - have been filtered using an idle time threshold of 10 minutes and through identification of changes in the angle of the vehicles' driving direction, derived from the tracked position points. As a heuristic approach, it was assumed that vehicle stops where the direction of the journey has not altered by more than 20 degrees does not qualify as a destination of the truck journey, instead we interpreted them as stops due to certain traffic conditions [22].

- In the second step, the pre-filtered stop locations have been compared against the subsequent departure points of the same vehicle, and thus the discontinued tracks were also removed from the dataset.
- In the third step, journey data were processed: timestamps, vehicle ID numbers (of different types), coordinates, and other journey description data have been stored in comma-separated value tables (CSV) to minimise the size of the files. As part of this process, all journey records have been labelled with a unique ID number. (Although identical numbers were assigned to each vehicle in the phase of separating journeys from GNSS tracks, it was essential to differentiate between all journeys of a truck with a separate code, so that the pertaining geometrical, temporal, and distance values could be calculated for the different vehicle movements.)

- A significant amount (about 50\%) of the dataset contained interrupted journey tracks which were mainly caused by the irregular switching of the OBUs, as many of the drivers turned the device off after leaving the Hungarian toll roads, but switched it on again before arriving at their final destination or entering Hungarian territory. Therefore, in the fourth step, these incomplete journey records have been removed from the database using a filtering algorithm that compares the ending coordinates of the previous journey with the starting coordinates of the subsequent trip and designate it as discontinued if the distance is higher than 0.1 geographical degree (around 10 kilometres).

- In the fifth step, driving and rest periods as well as travel times and rest times have been identified and calculated.

\subsection{Building the rest area database}

For this study, all rest areas along toll roads in Hungary, as well as rest areas in the border area, i.e., those located within a 200-metre distance from the border with Hungary, have been considered. In total, 434 rest areas have been listed, including 5 in Austria, Slovakia, and Slovenia. The elements 
Csendes B, et al. Where Truck Drivers Stop - Application of Vehicle Tracking Data for the Identification of Rest Locations and...

of the rest area database have been gathered from open online sources (IRU [23], DKV-Euroservice [24], and Truck Parking Europe [25]). The rest area parameters of the different sources have been crosschecked and confirmed based on on-site inspections to check and refine the capacity and the exact location of the facilities. The database includes motorway rest areas that are usually accessible from one direction only, parking lots at gas station, and other larger designated truck parking areas. The capacity of rest areas shows a variety from small stations of 5-10 spots up to the largest at border crossings, rest areas that usually boast over 100 places.

Toll road rest areas in Hungary are generally more frequent around the capital city of Budapest and along the main international transit corridors (Figure 2), where the facilities with more than 10 places are distributed rather evenly (10-20 kilometres from each other), while in the rest of the country rest areas may be 30-50 kilometres apart. (Let us note that double rest areas overlap on the maps in this paper, visualisation of rest areas with larger capacity is always prioritised.)

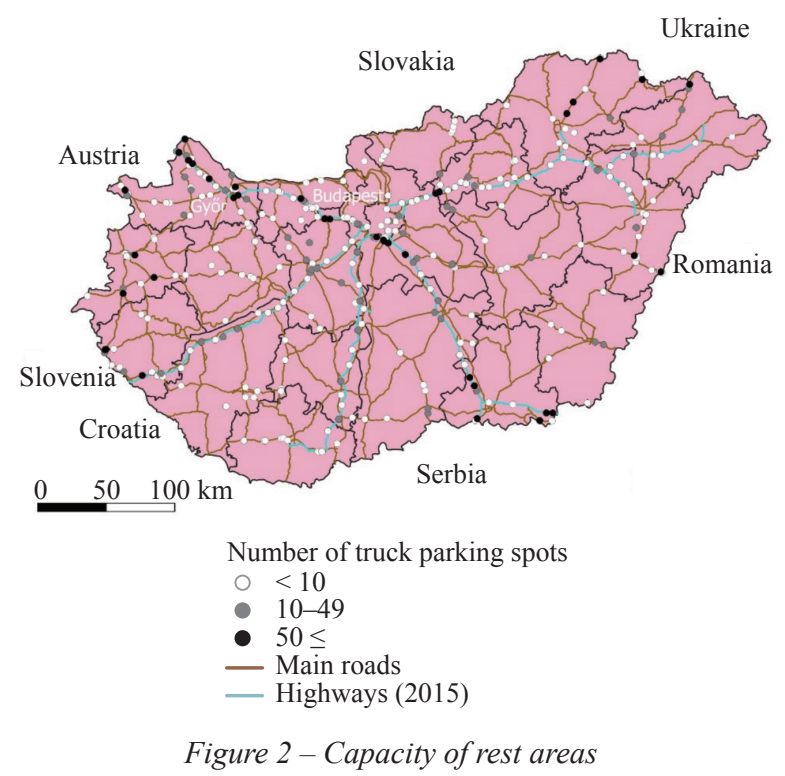

Some of the highways have unique characteristics in terms of rest area capacities, some of them have a higher number of relatively smaller rest areas, while other sections host fewer facilities with a higher average of parking capacity. About half of the analysed rest areas have a capacity below 10 places, and about one tenth of them have a capacity equal to or over 50 places - however, these large facilities host the majority of trucks along the main traffic corridors of Hungary (Table 1).
Table 1 -No. of rest areas by capacity groups

\begin{tabular}{|c|c|c|c||}
\hline \hline Capacity & $<10$ & $10-49$ & $50 \leq$ \\
\hline No. of rest areas & 257 & 139 & 38 \\
\hline
\end{tabular}

\subsection{Assignment of rest periods to rest areas}

As driving and rest periods, rest areas have also been identified by the above steps, assignment of rest periods to rest areas requires integration of the two databases. For this, buffer zones with a 200-metre radius have been drawn around each rest area so that all the possibly related truck stops could be assigned to the facilities, taking into account the inaccuracy of GNSS measurements. All the truck stop points falling within the 400-metres diameter circle have been linked to the given rest area. Although using this radius could potentially involve some overlapping between the zones and the inclusion of unrelated nearby truck stops (and thus it may require further filtering), the use of uniform buffer circles substantially decreases the data preparation time and are also more effective to compute than individual polygons with more complex geometry. Furthermore, parking outside the designated spots is also common around some of the crowded rest areas, thus buffer zones allow the identification of such driving behaviour in order to provide infrastructure managers with this relevant information.

\section{RESULTS AND DISCUSSION}

In this chapter, we present a general overview of rest time patterns, spatial distribution of stops by truck drivers, as well as a micro-scale analysis of a rest area. Some of the results provide insights into driving times, rest locations, and their spatial characteristics, illustrating how processed GNSS data may be applied for the analysis of road freight transport patterns.

\subsection{Rest time pattern analysis}

A general idea on the rest area usage of Hungarian roads may be given through the comparison of the lengths of driving and rest period. Figure 3 shows all temporal data of every journey that ended in one of the 434 identified rest areas. The sample - created from the aforementioned data processing - contains 4,813 journeys that have been 
filtered for the regulatory criteria, as driving times of less than 15 minutes and over 4.5 hours, and also breaks under 15 minutes and rest times of more than 24 hours have been excluded.

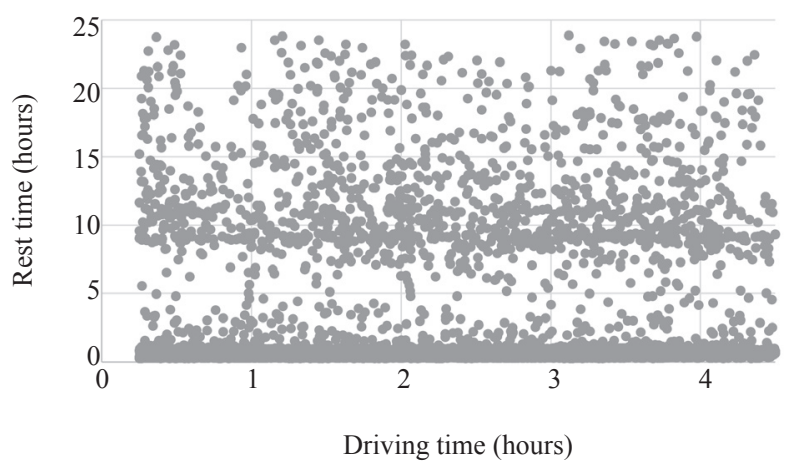

Figure 3 -Driving times and rest periods at rest areas

A concentration of rest periods is discernible around 0 to 1.5 hours and 8 to 10 hours. It is in line with the regulations for breaks and rests, thus seems to be an expectable and reasonable outcome. However, driving times tend to be evenly distributed along the horizontal axis, therefore, there is no indication of drivers attempting to exploit the maximum allowed driving time. Moreover, there is no correlation between the length of driving and resting periods: drivers may stop for a longer rest after a short drive just as easily as stopping for short rest after a longer drive. This may be explained by the fact that the daily driving limit is 9 hours (10 hours maximum twice a week) and this analysis contains only the sections ending at a rest area (and not for instance at the final destination), so daily driving patterns here cannot be considered as longitudinal examination.
The usage patterns tell a different story when the distribution of rest periods is plotted by the time of day. Based on Corro et. al. (2019) [8], it was expected to observe a higher number of trucks parked during the night with longer average rest periods. Instead, the highest number of trucks parked is associated with the hours around noon (10 a.m. to 3 p.m.); the elongation of rest periods starts already at 4 p.m., and after midnight these periods get shorter again (Figure 4). This phenomenon is explained by the fact that this database contains both national and international routes, and in domestic transport trucks most likely return to the company base, therefore their number is not adding to the truck count at rest areas at night.

Comparing the length of driving times and rest times, the balanced nature of regular stops is visible. Around every 2 hours on average the drivers stop for a break, but the length of rests is much more dependent on the time of day as seen in Figure 5. One possible explanation to the declining number of drivers stopping for longer rest periods or even departing from the rest area in the middle of the night may be the fact that night driving is generally less stressful and more predictable due to lower congestion (e.g. close to the capital city of Budapest or before crossings of Schengen borders) and that there are fewer factors that would result in delays. In light of the daily cycles observed within this dataset, further investigation is recommended as it may provide valuable insights for the infrastructural planning of a greener road freight network: for instance, for the usage of electric trucks, these patterns should be well understood and the electric network optimally prepared for the charging needs.

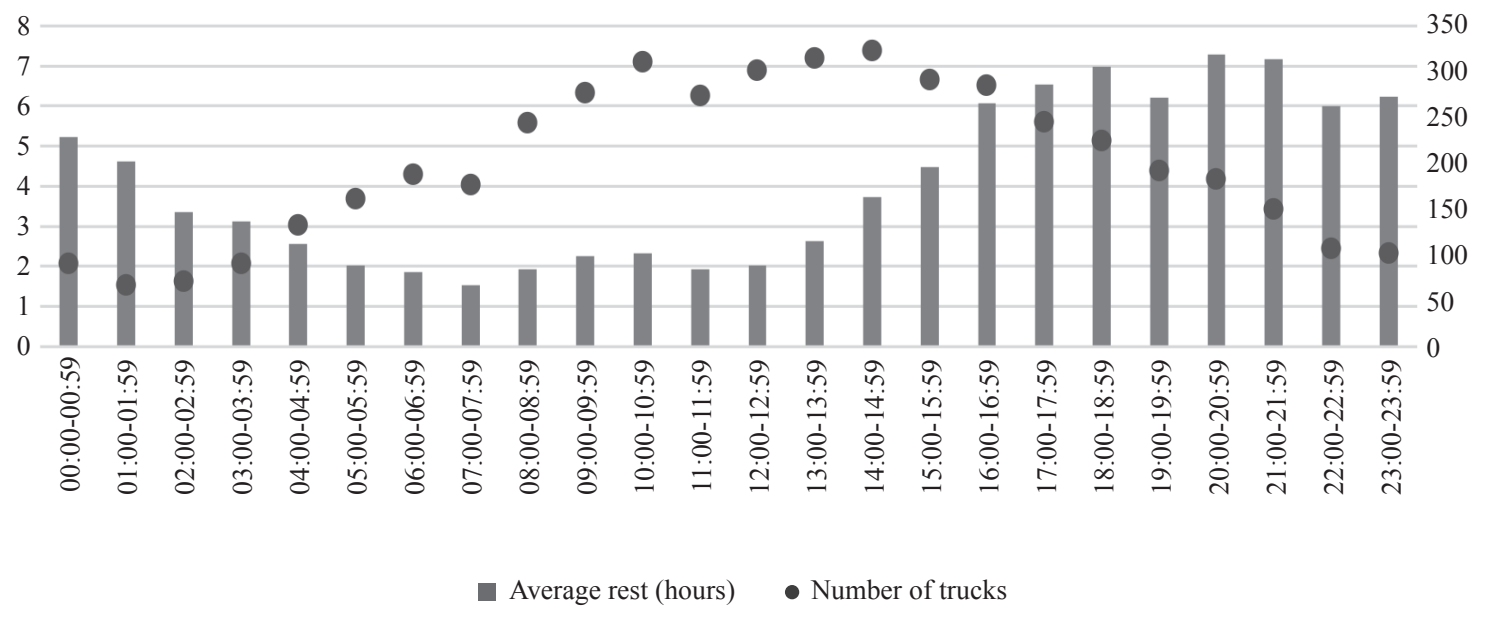

Figure 4-Number of trucks in rest areas and average length of truck drivers' rest periods (authors' edition) 


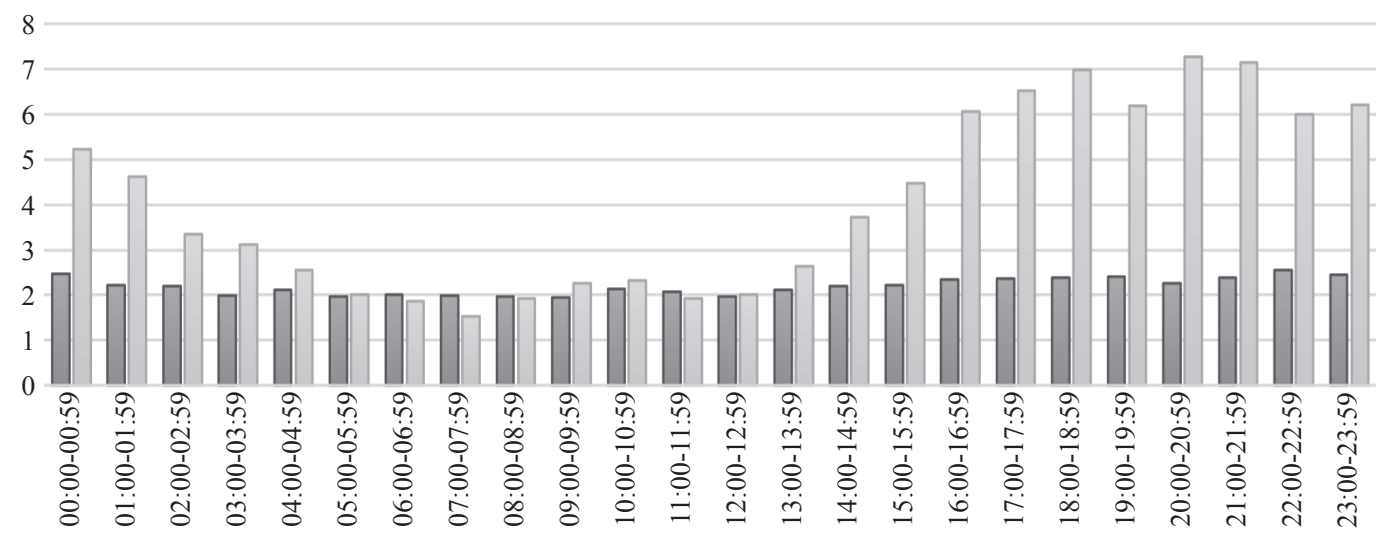

$\square$ Average driving (hours)

$\square$ Average rest (hours)

Figure 5 - Average length of truck drivers' driving and rest periods (authors'edition)

\subsection{Traffic volumes in rest areas}

Parking spots have been classified into ten deciles comprising equal number of rest areas, categorised according to the journey endpoints assigned, from the busiest to those witnessing the fewest stops by truck drivers (Figure 6).

The spatial distribution of the ten categories of the rest areas along the main transit routes reflects the capacity of these parking spots, as the heavier traffic can be observed at rest areas having more space. Busy rest areas marked with darker colours correlate with the main international traffic corridors of Hungary, they indicate more stops close to the capital city of Budapest (along the ring motorway M0 around Budapest), close to the city of Györ (the only large city towards Western Europe along TEN-T corridors), as well as at the state borders.

\subsection{Truck journeys of critical length}

As mentioned above, common European rules require that drivers stop after 4.5 hours of driving. To identify rest areas where more journeys of critical length end, driving times have been studied prior to the breaks. Figure 7 shows the distribution (deciles) of journeys above 3.5 hours in the 434 rest areas (considering this the minimum threshold of driving times turning into critical if there is no designated rest area or available parking). Darker colours indicate rest areas where these journeys are concentrated: particularly near the state borders with Austria, Romania, Slovakia, Slovenia, Serbia, and Ukraine, as well as in some further points of TEN-T corridors and close to the capital city of Budapest.

\subsection{Parking times}

Special attention has been paid to those rest areas where drivers spend longer time, supposedly their rest period. Stops above 45 minutes (Figure 8) and 9 hours (Figure 9) have been considered here. The proportion of rest times of the entire sample over 45 minutes were grouped into 5 categories: $0-20 \%, 20-40 \%, 40-60 \%, 60-80 \%$, and $80-100 \%$. Apparently and logically, most of the rest areas had a higher proportion of rest periods over 45 minutes and their spatial distribution is quite uniform. Rest areas with low proportion of stops above 45 minutes are mostly in services areas with limited capacity and thus fewer services where most drivers usually take short breaks. Notwithstanding, truck drivers spending their daily rest (longer than 9 hours) in rest areas tend to use the ones in inner parts of the country, more likely at high-capacity rest or service areas where more services are available

\subsection{Rest area analysis}

The exact locations of parked trucks provide relevant information about rest area usage, especially when parking takes place outside the designated lots (at the shoulders of the ramps, for instance), which can possibly indicate the saturation of the facility, particularly in the case of larger and busier rest areas.

One of the largest rest areas in Hungary, located along a TEN-T corridor, is presented in Figures $10 \mathrm{a}$ and $10 \mathrm{~b}$. The figures show both the driving times prior to arrival and resting times spent at the facility. The exact locations where trucks were parking are indicated. A vast majority of vehicles arrived at the rest area after a driving time of between 1 and 2 


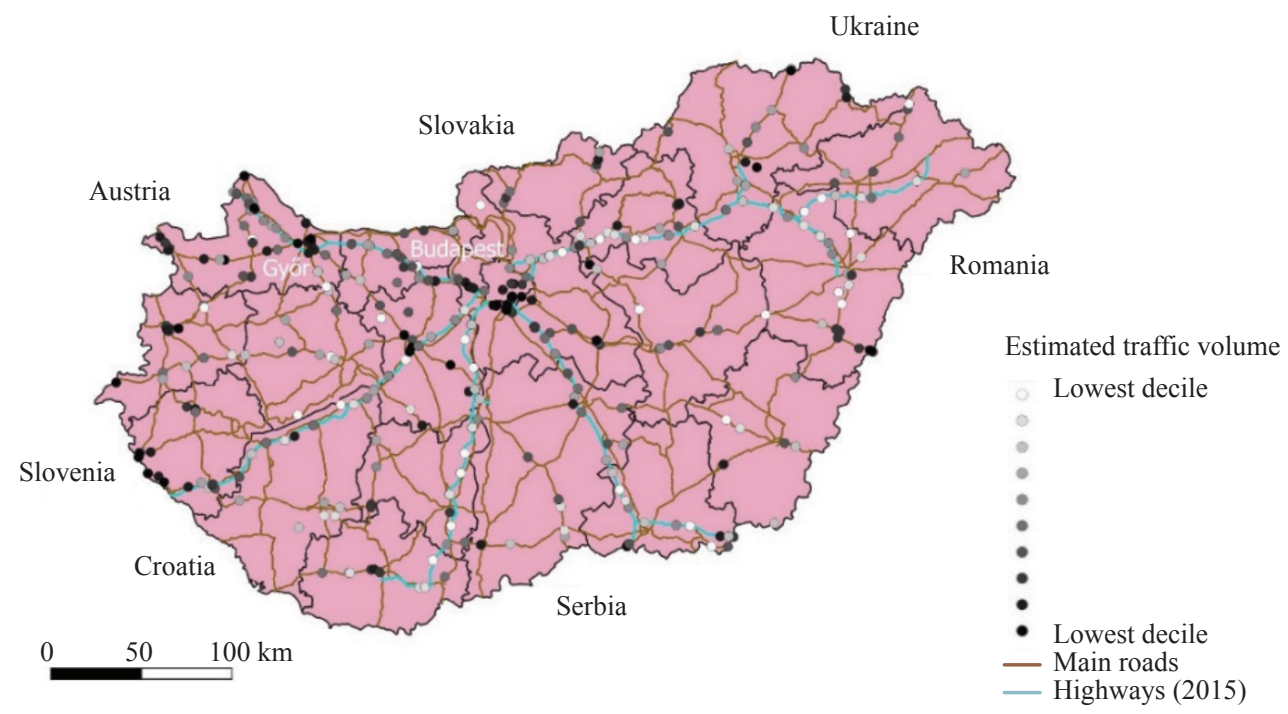

Figure 6 - Traffic volumes in truck rest areas (deciles)

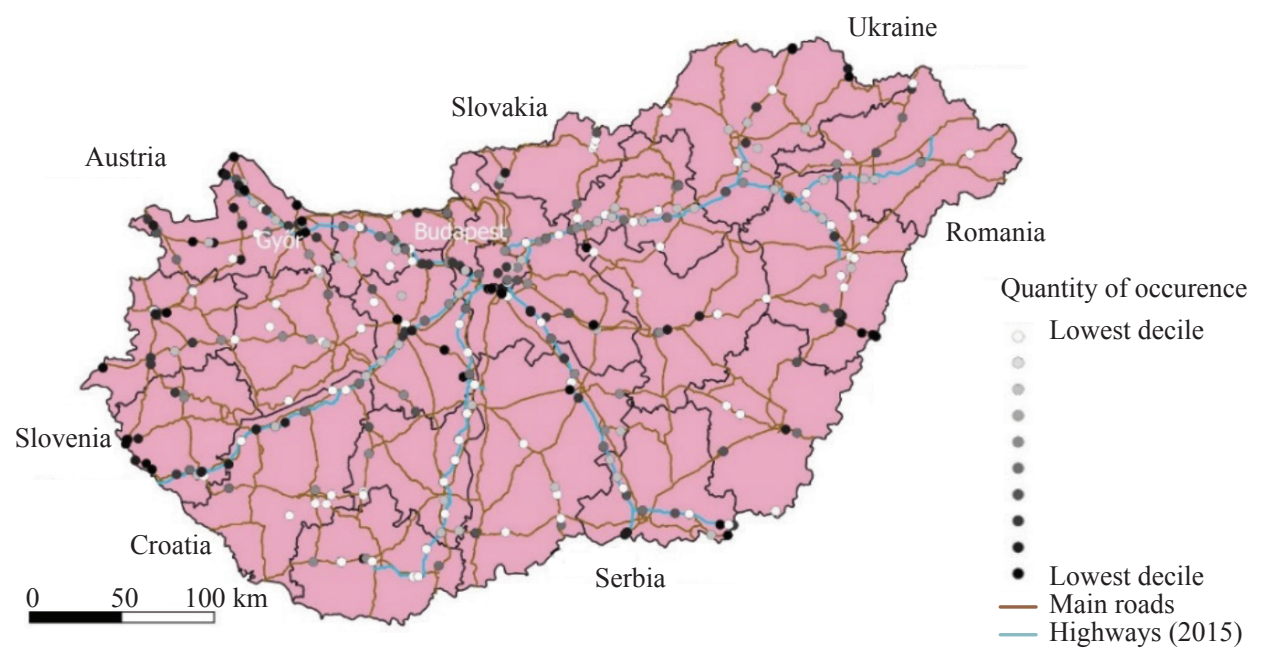

Figure 7 - Journeys above 3.5 hours of driving time at the rest areas of arrival (deciles)

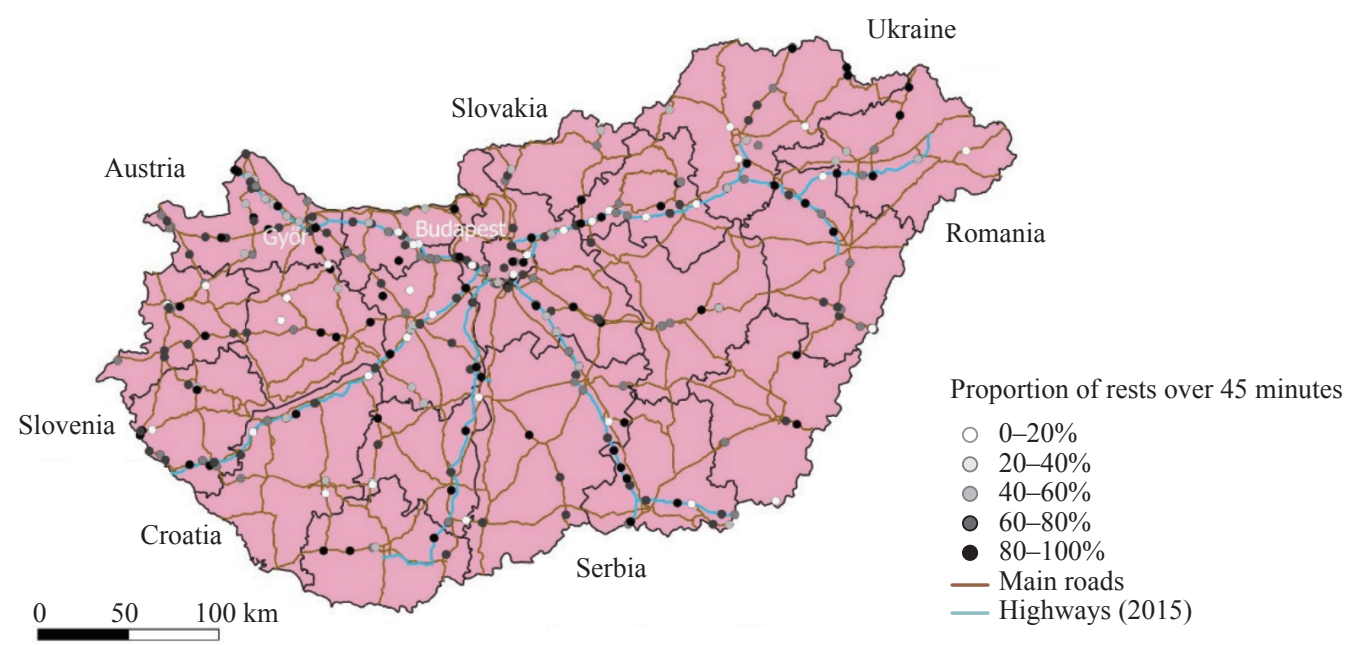

Figure 8 - Proportion of trucks stopping for more than 45 minutes (from all stops at the rest area) 


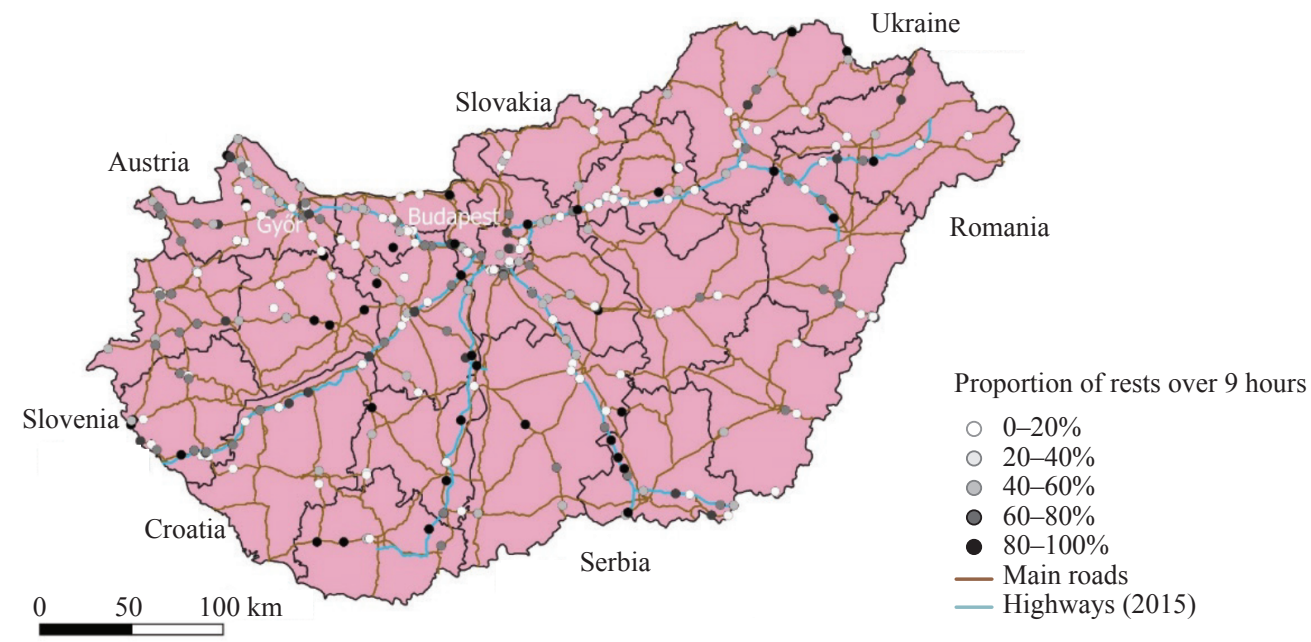

Figure 9 - Proportion of trucks stopping for more than 9 hours (from all stops at the rest area)

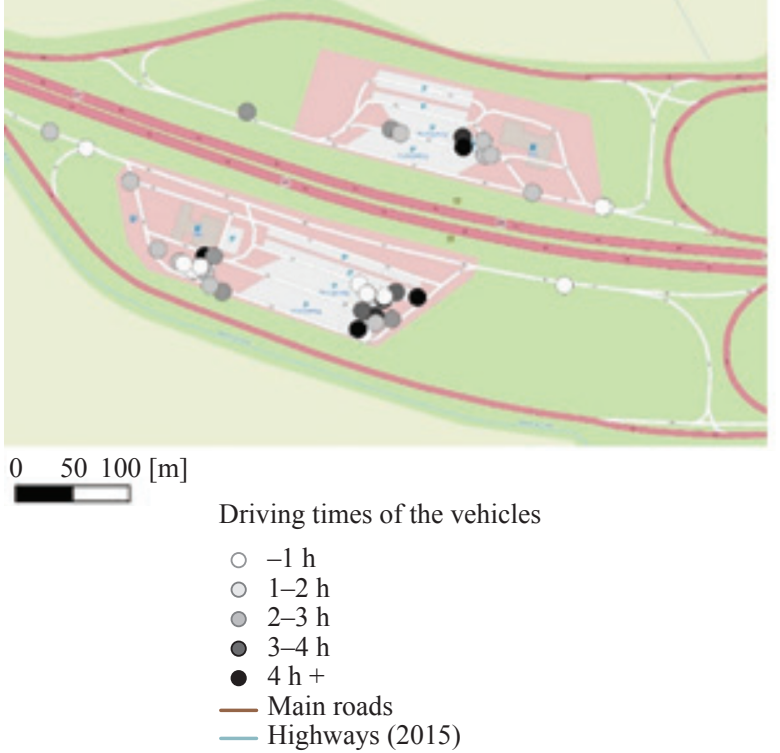

a) Driving times before arrival

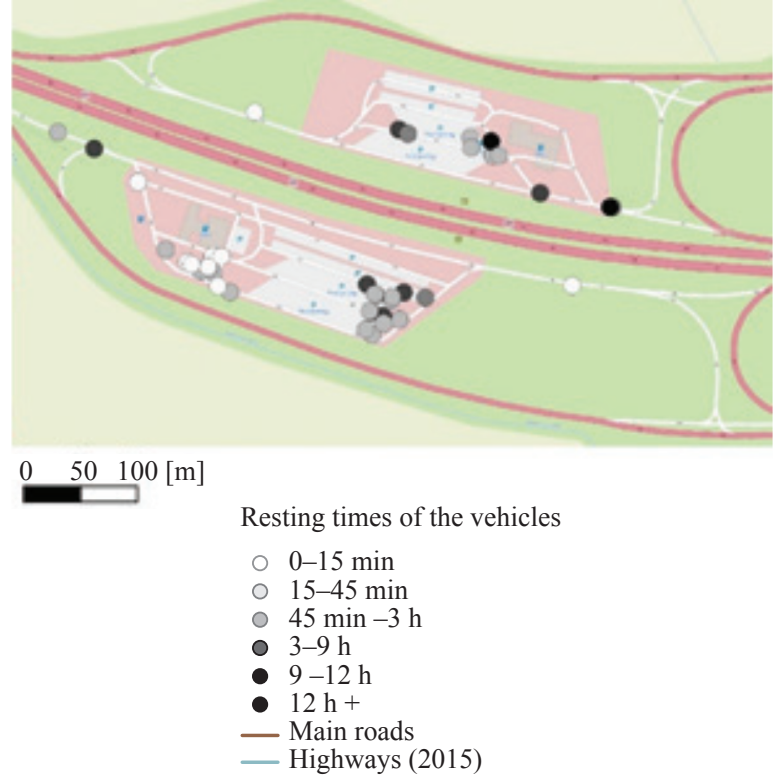

b) Resting times

Figure 10 - Trucks at a rest area

hours, or after shorter journeys. The calculation of rest times for arriving trucks indicates that short breaks (under 15 minutes) and short-stay parking (under 45 minutes) prevail. With regard to the spatial distribution, drivers apparently prefer parking spots close to the facility buildings, however, some of the shorter stops took place outside the designated parking area, along the entrance and exit ramps, suggesting that during certain rush periods drivers prefer to park their trucks outside the presumably crowded parking lots. Although this is only a brief insight into how rest areas are used, identification of both regular and unauthorised stops may be relevant for the reconsideration of the facilities and their op- eration, such as for the implementation of measures for better infrastructure management or enhanced traffic safety.

\section{CONCLUSION}

The maximum allowed driving time and the mandatory rest time is stipulated by European and national regulations. The strict norms require that truck drivers stop for a break or rest in clearly defined intervals, due to which rest areas along the main transport corridors may lack sufficient capacity to accommodate the needs of the mostly international freight traffic. Thus, predictability and prudent planning of 
the transports may be jeopardised, resulting in excessive stress and consequent risks of accidents, and potentially in exceeding driving times and the use of unauthorised parking spots.

In this article, GNSS tracking data from three leading Hungarian fleet management providers were analysed to assess driving and rest times. In this state-of-the-art study, derivatives of the raw GNSS tracking database have been used to estimate the different spatial and temporal mobility patterns of trucks using the main road network in Hungary. With the above presented processing methodology of tracking data (locations and timestamps), it was possible to reveal the daily course of driving and rest times, as well as the number of trucks parking in the studied rest areas, thus characterising the temporal driving patterns and rest area usage on the domestic main road network (RQ1). A key advantage of this method is that it provides relevant information about road freight traffic flows without any additional on-site surveys.

In the spatial analysis, truck stops of 434 rest areas in Hungary (including a handful of facilities right across the border in Austria, Slovakia, and Slovenia) have been examined, providing statistics not only about the traffic volume but also both the time spent at the parking facilities and the driving time prior reaching the designated spots. In terms of the spatial characteristics of rest area utilisation (RQ2), facilities hosting the highest number of truck stops along the main transport corridors are concentrated in close proximity of the economic centre of the country (the capital city of Budapest) and the parking facilities with the highest rate of longer waiting times and longer previous journeys are situated at the busiest border crossings. Comprehensive real-time rest area capacity monitoring systems and applications (e.g. for mobile devices) could provide a solution, on the basis of reliable GNSS information gathered by fleet toll service providers (and this data could also be utilised by other stakeholders within the traffic domain for development purposes).

A micro-scale analysis demonstrated that at busy rest areas trucks may systemically tend to park outside the designated spots along both the entry and the exit ramps, indicating the saturation of the rest area and also posing road safety risks for other vehicles and people (including passengers in cars and motorcyclists) using the exit lanes. In light of these first insights, this approach can be applied to extend the analysis of rest area infrastructures (RQ3) by a detailed study of a specific rest area or a comprehensive review of facilities along a corridor. This method would support researchers, road engineers, and traffic managers in understanding parking patterns and subsequently deciding on a revision of traffic management at rest areas (e.g. reorganisation of parking spots, increase of parking capacities, enhancement of road safety, particularly for vulnerable road users) or reconsider the design of road infrastructures in rest areas (e.g. distribution of parking places, access routes by vehicles and on foot). Findings are expected to contribute to policy-making as well, especially in terms of achieving aims related to priority actions of the EU directive on the deployment of Intelligent Transport Systems in the field of road transport, namely the provision of reservation services for safe and secure parking places for trucks and commercial vehicles [26].

There are many ways to extend the analysis of GNSS datasets for road freight traffic optimisation, but for the present study two key future research directions are of paramount importance. First, onsite validation of similar GNSS tracking data could improve the reliability of the presented method. It could be a useful technique to also gather auxiliary data (such as freight category, nationality, and other characteristics). However, this may be time-consuming and costly, taking into account that relevant information could have been gathered by applying the above methods without on-site surveys. It is worth noting that a significant barrier for further analyses of the present dataset is posed by the lack of vehicle category attributes in the dataset, which could facilitate the assessment of the vehicle size and hence the parking spot size needed for the different trucks. This kind of additional information would increase the opportunity to carry out more detailed analyses and find tailor-made solutions for specific rest areas. Second, another possible future direction of the research is to perform reliable calculations on the number of trucks simultaneously using the rest area; however, this would require significant computing capacities to jointly process the timestamps and the GNSS coordinates. The synchronised spatial-temporal data-gathering could also allow data users to analyse the correlation between the saturation of the rest areas and the use of the unauthorised parking spots and certain short-stop facilities such as truck wash or gas stations. 


\section{ACKNOWLEDGMENT}

This study is based on data from a project (Enhancing the Participation of Hungary in the TEN-T Corridors) funded by the EU Connecting Europe Facility.

\section{Dr. CSENDES BÁLINT ${ }^{1}$}

(Felelös szerzö)

E-mail: csendes.balint@kti.hu

\section{ALBERT GÁBOR}

E-mail: albert.gabor@kti.hu

Dr. SZANDER NORINA ${ }^{1}$

E-mail: szander.norina@kti.hu

Dr. MUNKÁCSY ANDRÁS ${ }^{1}$

E-mail: munkacsy.andras@kti.hu

${ }^{1}$ KTI Közlekedéstudományi Intézet Nonprofit Kft.

1119 Budapest, Than Károly u. 3-5. Magyarország

\section{AHOL A TEHERGÉPKOCSI-VEZETÖK MEGÁLLNAK: FLOTTAKÖVETÉSI ADATOK ALKALMAZÁSA A PIHENÖHELY-HASZNÁLATI ÉS VEZETÉSI MINTÁZATOK VIZSGÁLATÁRA}

\section{KIVONAT}

A közúti közlekedés alapvetö szerepet játszik az európai árufuvarozásban, ezért az áruforgalmat akadályozó tényezőket érdemes megvizsgálni és a zavartalan müködést célzó lehetséges jövőbeli beavatkozásokat valós adatokra támaszkodva elökésziteni. A közúti árufuvarozás kapcsán az egyik ilyen kritikus szempont a tehergépjármüvek kötelezö megállása, annak helyszíne és idötartama. Elöfordul, hogy a jogszabályok által elöirt pihenöidők betartása nehézségekbe ütközik, ami fennakadást okozhat az ellátási láncban. A tehergépkocsiforgalom volumenének és a közúti infrastruktúra kihasználtságának becslése kihívás elé állitja a kutatókat, a müholdas nyomkövetési adatok megjelenése azonban nagy mennyiségü adatot biztosit az elemzésekhez. Jelen tanulmányban olyan új módszert mutatunk be, amely alkalmas a vezetési és a pihenési mintázatok vizsgálatára. Az adatállományból a földrajzi pozíciók és a hozzájuk tartozó idöbélyegek egymáshoz rendelésével elvégeztük az egyes pihenöhelyek használatának térbeli és idöbeli vizsgálatát. Az eredmények alapján következtetések vonhatók le a tehergépkocsik magyarországi úthálózaton és pihenöhelyein eltöltött idejének napi lefutására; az egyes pihenőhelyek látogatottságának gyakoriságára és idötartamára; valamint a pihenőhelyek mikroszinten értelmezett használati szokásaira vonatkozóan. Az ilyen vizsgálatok az árufuvarozás költséghatékonyságának növelését szolgáló fejlesztések mellett az infrastruktúra optimális használatát elösegitö beavatkozások előkészitését is támogathatják.

\section{KULCSSZAVAK}

GNSS nyomkövetés; tehergépjármü-pihenöhelyek; kötelezö pihenési idö; tehergépjármü-szabályozás, tehergépjármü-vezetési szokások; közúti teherszállitás.

\section{REFERENCES}

[1] Hungarian Central Statistical Office. Freight transport by mode. 2021. Available from: http://www.ksh.hu/stadat files/sza/hu/sza0002.html [Accessed 17th May 2021].

[2] CEDR. Trans-European Road Network, TEN-T (Roads): 2019 Performance Report. Conference of European Directors for Roads, 2020.

[3] Magyar Közút. [Cross-sectional traffic data of Hungarian national public roads, 2019]. 2020. Available from: https://internet.kozut.hu/download/az-orszagos-kozutak-2019-evre-vonatkozo-keresztmetszeti-forgalma/ [Accessed 16th June 2021].

[4] Regulation (EC) No 561/2006 of the European Parliament. Available from: https://eur-lex.europa.eu/ legal-content/en/TXT/?uri=CELEX:32006R0561 [Accessed 16th June 2021].

[5] Regulation (EU) 2020/1054 of the European Parliament. Available from: https://eur-lex.europa.eu/legal-contentEN/TXT/HTML/?uri=CELEX:32020R1054 [Accessed 16th June 2021].

[6] European Commission. Sustainable and Smart Mobility Strategy - Putting European transport on track for the future. $\operatorname{COM}(2020) 789$ final, 2020. Available from: https://eur-lex.europa.eu/legal-content/EN/TXT/HTML/?uri=CELEX:52020DC0789\&from $=\mathrm{EN} \quad$ [Accessed 17th May 2021].

[7] Sipos T, Szabó Z, Török Á. Spatial econometric cross-border traffic analysis for passenger cars - Hungarian experience. Promet - Traffic\&Transportation. 2021;33(2): 233-46. DOI: 10.7307/ptt.v33i2.3641

[8] Corro KD, Akter T, Hernandez S. Comparison of overnight truck parking counts with GPS-Derived counts for truck parking facility utilization analysis. Transportation Research Record. 2019;2673(8): 377-387. DOI: 10.1177/0361198119843851

[9] Ioannou P, de Almeida Araujo Vital F. Intelligent parking assist for trucks with prediction. National Center for Sustainable Transportation, 2018. Available from: https:// escholarship.org/uc/item $/ 7 \mathrm{dm} 0 \times 5 \mathrm{mr}$

[10] U.S. Department of Transportation. Jason's Law Truck Parking Survey Results and Comparative Analysis. Federal Highway Administration, Office of Freight Management and Operations, 2015. Available from: https://ops. fhwa.dot.gov/freight/infrastructure/truck_parking/jasons_law/truckparkingsurvey/jasons_law.pdf [Accessed 17th May 2020].

[11] Karam A, et al. Towards deriving freight traffic measures from truck movement data for state road planning: A proposed system framework. ISPRS International Journal of Geo-Information. 2020;9(10): 606. DOI: 10.3390/ ijgi9100606

[12] Minnesota Safety Rest Area Programs. Commercial truck usage nighttime parking demand analysis. 1998.

[13] Iowa StateUniversity / Iowa Department of Transportation. Commercial Vehicle Parking. 1999. Available from: https://intrans.iastate.edu/app/uploads/2018/03/truckpar. pdf

[14] Boris C, Brewster R. A comparative analysis of truck parking travel diary data. Transportation Research Record. 2018:2672(9): 242-248. DOI: 10.1177/ 0361198118775869 
Csendes B, et al. Where Truck Drivers Stop - Application of Vehicle Tracking Data for the Identification of Rest Locations and...

[15] Anderson JC, Hernandez S, Jessup EL, North E. Perceived safe and adequate truck parking: A random parameters binary logit analysis of truck driver opinions in the Pacific Northwest. International Journal of Transportation Science and Technology. 2018:7(1): 89-102. DOI: 10.1016/j.ijtst.2018.01.001

[16] Torrey IWF, Murray D. Managing critical truck parking tech memo \#2: Minnesota case study - Utilizing truck GPS data to assess parking supply and demand. American Transportation Research Institute; 2017. Available from: https://truckingresearch.org/wp-content/uploads/2017/02/Managing-Critical-Truck-Parking-Tech-Memo-2-02-2017-1.pdf

[17] Haque K, Mishra S, Paleti R, Golias MM, Sarker AA, Pujats K. Truck parking utilization analysis using GPS data. Journal of Transportation Engineering, Part A: Systems. 2017:143(9): 04017045. DOI: 10.1061/ JTEPBS.0000073

[18] Nevland EA, Gingerich K, Park PY. A data-driven systematic approach for identifying and classifying longhaul truck parking locations. Transport Policy. 2020;96: 48-59. DOI:10.1016/j.tranpol.2020.04.003

[19] Karam A, Illemann TM, Reinau KH. GPS-derived measures of freight trucks for rest areas: A case-study based analysis. 2020 IEEE International Conference on Indus- trial Engineering and Engineering Management (IEEM). DOI: 10.1109/IEEM45057.2020.9309748

[20] Albert G. [The new national origin-destination matrices (OCF-2016) as the cornerstones of transport planning]. Közlekedéstudományi Szemle. 2017:67(5): 5-15. Hungarian.

[21] KTI Institute for Transport Sciences NLtd. [Elaboration of the national origin-destination traffic survey and matrices (OCF-2016)]. TEN-T Analyses, Budapest, 2017. Hungarian.

[22] Pusztai Á, Kiss I. [A methodological breakthrough - developing OD matrices of heavy goods vehicles]. Közlekedéstudományi Szemle. 2017:67(5): 44-53. Hungarian.

[23] Parking Area Search. Available from: https://www.iru. org/apps/transpark-app [Accessed 30th June 2021].

[24] DKV fuel station POI. Available from: https://www. dkv-mobility.com/en/fuelling/poi-navigation-data/ [Accessed 30th June 2021].

[25] Secure bookable truck parking locations in Hungary. Available from: https://www.truckparkingeurope.com/ secure-truck-parking-overview/hungary/ [Accessed 30th June 2021].

[26] Directive 2010/40/EU. Available from: https://eur-lex. europa.eu/legal-content/EN/TXT/HTML/?uri=CELEX:32010L0040 [Accessed 1st Oct. 2021]. 